\title{
Microplastic Contamination in Blood Cockles and Mussels in Bandon Bay, Suratthani Province, Thailand
}

\author{
Watcharee Ruairuen ${ }^{1, *}$, Kittiya Chanhun ${ }^{1}$, Wassana Chainate ${ }^{1}$, \\ Natenapa Ruangpanupan ${ }^{2}$, Paphassara Thipbanpot ${ }^{1}$ and Naranun Khammanee ${ }^{1}$

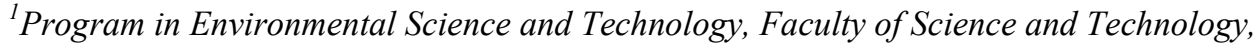 \\ Suratthani Rajabhat University, Suratthani 84100, Thailand \\ ${ }^{2}$ Program in Environment and Resource, Mahidol University, Nakhon Pathom 73170, Thailand
}

('Corresponding author's e-mail: watcharee.rua@sru.ac.th)

Received: 4 July 2021, Revised: 9 September 2021, Accepted: 24 September 2021

\begin{abstract}
Widespread microplastic contamination has been of growing concern worldwide and poses a growing threat to the marine environment, particularly the impact on the food chain. This study quantified the presence of microplastics in two bivalves of commercial interest at the Pak Kadae Estuary, Bandon Bay, Surat Thani province, Thailand: green mussel Perna viridis (L.) and cockles Tegillarca granosa (L.). Data collection was carried out over two seasons: dry season (April - May 2019) and wet season (June - August 2019). Microplastics were extracted using a $10 \%$ potassium hydroxide (KOH) digestion method and then identified under a microscope. Results confirmed the presence of microplastics in both cockles and green mussels, during the dry season, with mean concentrations of $0.30 \pm 0.07$ and $1.26 \pm 0.10$ items/individual, respectively. During the wet season, the mean microplastic concentrations were $0.20 \pm 0.07$ and $0.56 \pm 0.15$ items/individual in the cockles and green mussels, respectively. There was a greater concentration of microplastics found in green mussels compared to cockles $(\mathrm{P}<0.05)$ with no seasonal variation being observed. Five different shapes of microplastics, including fiber, fragment, pellet, rod, and film, were detected in the soft tissues of the bivalves. Fibers were the most common shape in green mussels (49-69\%) during both seasons. Cockles, in contrast, predominantly contained the pellet shape in the dry season (49\%) and fiber in the wet season (59\%). In addition, the microplastic concentrations were positively correlated to shell heights of the bivalves $(\mathrm{P}<0.01)$. The number of microplastics recorded in the two commercially exploited species demonstrated the need for controlling plastic pollution in coastal ecosystems.
\end{abstract}

Keywords: Microplastics, Contamination, Cockles, Green mussel, Coastal ecosystem

\section{Introduction}

Plastic debris have become a major threat to our planet; this is due to the rapid increase in production of disposable plastic products, overwhelming global efforts to dispose of them properly. An estimated $10 \%$ of plastics will eventually end up in our oceans and seas [1] due to inappropriate management by consumers. It was estimated that more than 5 trillion plastic particles float on the ocean's surface [2] with many more in water columns and marine sediments. Marine plastic debris accounted for about $92.4 \%$ of marine pollutants [3]. Plastics can be degraded slowly by microbes, sunlight, or mechanical abrasion [4] into microplastics, defined here as fragments smaller than $5 \mathrm{~mm}$ in size [5]; these fragments require several centuries, or even thousands of years, to degrade further [6].

It is now well-known that microplastics are highly persistent in the environment and are accumulating in different ecosystems at increasing rates. Microplastics in the coastal and marine environment come from a variety of sources including tourism, agriculture, fisheries, and industrial sectors. In addition, microplastics may be introduced into the water and sediments as micro-particles, such as fragments of fishing gear, packages, drink bottles, synthetic textiles, car tires, paints, cosmetics, personal care products, and electronic equipment, among others [7-8]. Due to their very small size, microplastics are easily mistaken for food and ingested by a wide range of marine organisms from planktonic invertebrates to large marine mammals with different feeding-mechanisms (e.g. filter-feeding or deposit feeding) [9]. Moreover, due to microplastics' capacity to adsorb, act as carriers of 
contaminants, and leach toxic substances to marine biota, they may also pose further health risks [10-13]. The smaller particles of microplastics tend to have stronger adsorption energy of pollutants in the aquatic environment and pose a potential threat to aquatic life [14].

Microplastics have been detected in commercial seafood sold in markets for human consumption [15-18]; they've even been found in beer, drinking water, honey, sugar, and salt [19-22]. These findings raise concerns regarding humans ingesting microplastics via consumption of contaminated marine species and the potential effects on human health. Additionally, seafood provides nearly three billion people with a substantial proportion of their animal protein intake, potentially magnifying the impacts on human health [23]. Microplastic contamination of bivalves is of particular concern, because many species in this class are consumed by humans. Several studies reported the presence of microplastics in marine animals consumed as food by humans. For example, a study of microplastics in commercial mussels from Belgium showed that the number of microplastic particles varied from 3 to 5 fibers per 10 gram of mussels [24]. Another study of microplastics in commercial bivalves in China also reported mean particle concentrations (size range $5-5000 \mu \mathrm{m}$ ) ranging from 2 to 11 items/gram and from 4 to 57 items/individual bivalve [15]. The proportion of bivalves, along the coast of France, contaminated with microplastics ranged from 34 to $58 \%$ with abundance averages of $0.76 \pm 0.40$ and $2.46 \pm 1.16$ items /individual in blue mussels and common cockles, respectively [25].

Even though they have been identified in many regions, relatively little is known about the abundance of microplastics in bivalves, especially, in the middle Gulf of Thailand. Surat Thani Province, located on the Gulf of Thailand, has undergone rapid industrial development and urban expansion in the past several years. Intensive, large-scale commercial fisheries, urban expansion, and plastic contamination are all occurring along this coastline. Consequently, these recent anthropogenic activities pose a substantial threat of microplastic pollution in both human populations and the local ecosystem. Microplastics, found in the stomachs of 165 varieties of commercially important fish from the lower Gulf of Thailand, were present in $66.67 \%$ of specimens tested. Most of the recovered particles $(41.47 \%)$ were transparent plastics [26]. These findings show that the local population is likely vulnerable to microplastic exposure through the consumption of seafood and related food products. The exposure levels are poorly known in general, and the potential effects on consumers are still unclear. Therefore, it is important to quantify the presence of microplastics in edible tissues of bivalve species, providing information that can be used for a risk assessment.

In the present study, two species of bivalves, green mussel (Perna viridis) and cockles (Tegillarca granosa (L.)), were evaluated for microplastic contamination, since both species are commercially important seafood products in Thailand. These species live in different habitats and are commonly found in Bandon Bay, Surat Thani province, Thailand, one of the most productive bivalve aquaculture regions. As such, the aims of this research project were to: (i) examine the presence of microplastics in green mussels and blood cockles (ii) identify morphological characteristics of microplastics, and (iii) explore the seasonal variation of microplastic contamination.

\section{Materials and methods}

\section{Sample collection}

Samples of mussels and cockles sold for human consumption were collected from April through August 2019 from Pak Nam Kadae local seafood market ( $9^{\circ} 12^{\prime} 34.6032^{\prime \prime}$ N, $99^{\circ} 28^{\prime} 42.6576^{\prime \prime}$ E) and fishermen in Wat Khoa Pranim ( $\left.9^{\circ} 12^{\prime} 36.9756^{\prime \prime} \mathrm{N}, 9^{\circ} 28^{\prime} 39.9684^{\prime \prime} \mathrm{E}\right)$, Bandon Bay, Surat Thani Province, Thailand (Figure 1). This seafood market is a major producer in a region where the majority of bivalves are caught in the Pak Kadae Estuary in Bandon Bay. The Thai climate is characterized by an annual cycle of wet and dry seasons, with long hours of sunshine, fairly high temperatures year-round and high humidity [27]. Surat Thani has a dry season from February to May, and a wet season start in June and continued until January. The average minimum temperature is approximately $23{ }^{\circ} \mathrm{C}$ which occurs during November-January, while the maximum temperature could reach up $36{ }^{\circ} \mathrm{C}$ during March-June. The region is also home to intensive coastal aquaculture, especially bivalve species such as cockle, mussel, and oyster - a result of high nutrient and organic matter availability from freshwater discharge. These conditions result in an abundance of phytoplankton, supporting the ecosystem and aquaculture of the area. Data collected in 2019 from April to May and June to August were intended to capture microplastics contamination during the dry and wet seasons, respectively.

A total of 30 cockles and 30 mussels were sampled each month from April to August 2019. In total, 150 mussels and 150 cockles were collected. Samples were packed in boxes with an ice bag, transported to the laboratory, and then stored at $-20{ }^{\circ} \mathrm{C}$ for subsequent analysis. In the laboratory, the shells were 
rinsed four times with distilled water to remove sediment, biofilm and other debris prior to opening them for soft-tissue collection. The shell length and height of individual samples were measured using a Vernier caliper. After measurement, the bivalves were then shelled and their soft tissue wet weights were recorded.

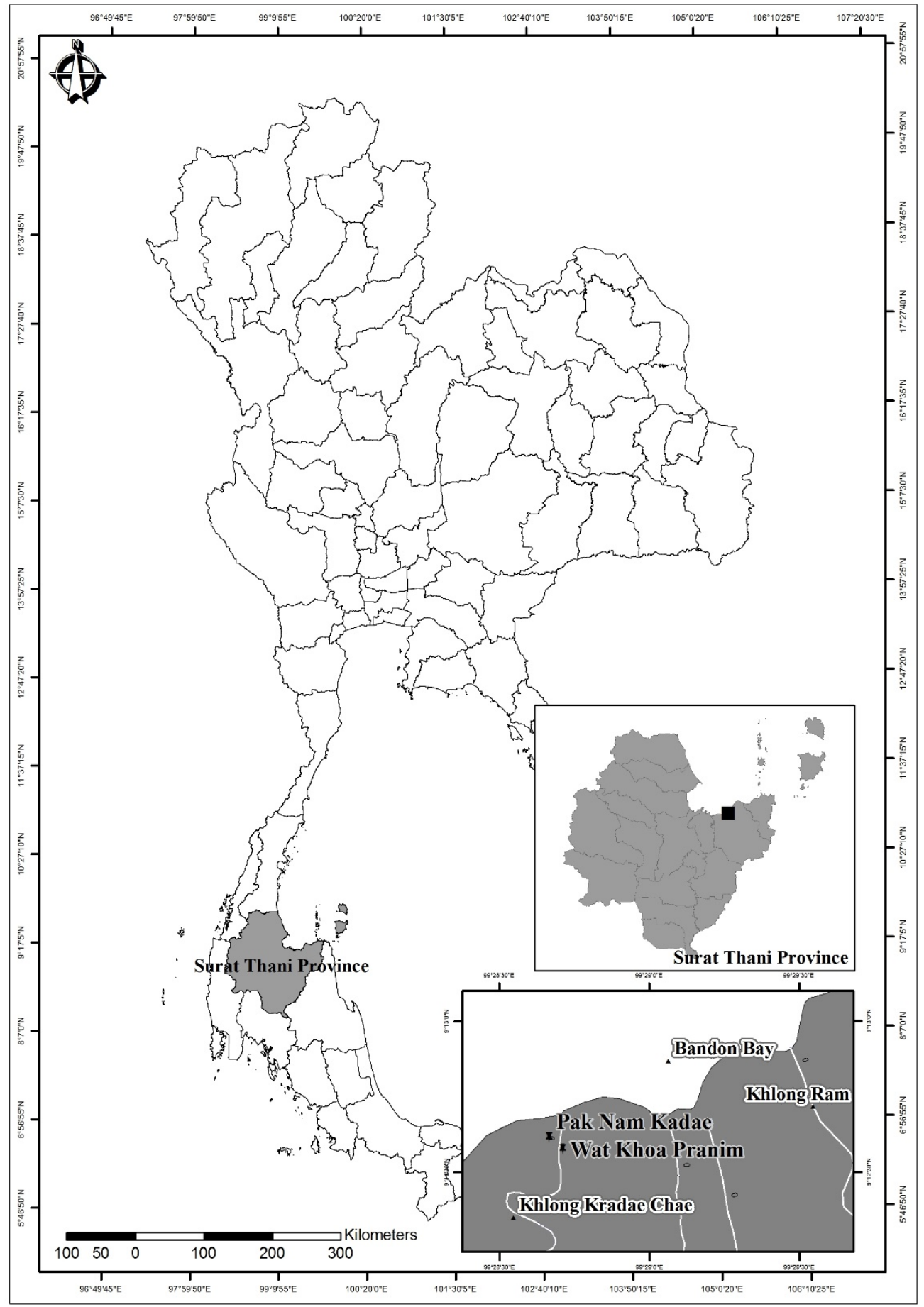

Figure 1 Map of sampling locations in Bandon Bay, Surat Thani Province, Thailand. 


\section{Microplastics analyses}

All laboratory equipment used was made of glass or metal to avoid overestimation of the microplastic concentration in bivalves from airborne, container, or tool contamination. To separate the microplastics from the bivalve tissues, we followed the protocol of Munno et al. [28], with some minor modifications. The samples were placed into a labelled, $250 \mathrm{~mL}$ glass beaker. Approximately $150 \mathrm{~mL}$ of $10 \% \mathrm{KOH}$ and $20 \mathrm{~mL}$ of $30 \% \mathrm{H}_{2} \mathrm{O}_{2}$ were added to each glass beaker to digest the soft tissues. The beakers were then sealed with aluminum foil and placed in an oven at $60{ }^{\circ} \mathrm{C}$ for $24 \mathrm{~h}$. At the same time, the mixture was agitated every $8 \mathrm{~h}$ to remove all organic matter. The digestion was completed when the solution was clear and yellow, showing no organic residue. The solution then was filtered over glass fiber filter membranes (GF/B, $1.0 \mu \mathrm{m}$ pore size $47 \mathrm{~mm}$ diameter, Whatman, U.K.). Finally, each filter was placed into a cleaned and covered glass petri dish, which was secured with tape and stored for observation under a microscope. All filters were observed carefully, following a z-shaped pattern from left to right under a microscope. The numbers, shapes, and colors of microplastics on filters were identified and recorded as described in a previous study [15]. Microplastics were counted and categorized as either fiber, fragment, pellet, or film and classified into a color category according to the dominant surface color.

\section{Statistical analyses}

All statistical analyses were performed using SPSS 20.0 software [29]. Normality of data was tested using the Shapiro-Wilk test and non-parametric data log, transformed where applicable. Comparisons between datasets were assessed using a t-test or ANOVA with a post-hoc Tukey test, or a Kruskal-Wallis test for non-parametric data. A significant difference is attributed where $\mathrm{P}<0.05$. Pearson's coefficient was chosen, and the significance level was set at 0.05 and 0.01 .

\section{Results and discussion}

The shell dimensions and body weight of cultured cockles and mussels from April to August 2019 are shown in Table 1. The average shell length and height, and the soft tissue wet weight for cockles ranged from 3.90 to $4.73 \mathrm{~cm}, 2.16$ to $3.86 \mathrm{~cm}$, and 6.37 to $11.54 \mathrm{~g}$, respectively. The average shell length and height, and the soft tissue wet weight of mussels varied from 8.15 to $8.77 \mathrm{~cm}, 3.41$ to $4.71 \mathrm{~cm}$, and 13.54 to $19.96 \mathrm{~g}$, respectively. The least and greatest tissue weights for both species of bivalves were measured in April and May, respectively.

Table 1 Shell dimensions and body weights of the cultured cockles and mussels in April-August 2019.

\begin{tabular}{llccc}
\hline Species & Month & Length $\mathbf{( c m )}$ & Height $(\mathbf{c m})$ & Soft tissue Weight (g) \\
\hline Cockle & April & $4.53 \pm 0.42$ & $3.44 \pm 0.17$ & $6.37 \pm 0.90$ \\
& May & $3.94 \pm 0.34$ & $3.20 \pm 0.33$ & $11.54 \pm 1.46$ \\
& June & $4.14 \pm 0.61$ & $3.47 \pm 0.63$ & $7.28 \pm 0.62$ \\
& July & $4.03 \pm 0.07$ & $2.16 \pm 1.53$ & $6.82 \pm 0.37$ \\
& August & $4.74 \pm 0.26$ & $3.86 \pm 0.10$ & $8.45 \pm 1.18$ \\
\hline \multirow{2}{*}{ Mussel } & April & $8.28 \pm 0.82$ & $3.50 \pm 0.35$ & $13.54 \pm 0.61$ \\
& May & $8.30 \pm 0.86$ & $3.50 \pm 0.59$ & $19.96 \pm 6.54$ \\
& June & $8.15 \pm 0.80$ & $3.41 \pm 0.56$ & $18.60 \pm 3.81$ \\
& July & $8.70 \pm 0.73$ & $4.65 \pm 0.33$ & $18.19 \pm 7.05$ \\
& August & $8.77 \pm 0.97$ & $4.71 \pm 0.40$ & $18.45 \pm 6.38$ \\
\hline
\end{tabular}

The average abundance of microplastics ranged from $0.28 \pm 0.05$ to $2.14 \pm 0.36$ items/individual in cockles and $0.65 \pm 0.13$ to $3.43 \pm 0.21$ items/individual in mussels throughout the period of the study (Table 2). Averages (Mean $\pm \mathrm{SD}$ ) of $0.30 \pm 0.07$ and $1.26 \pm 0.10$ items/individual were detected in cockles and mussels, respectively, during the dry season. On the other hand, the mean microplastic concentrations were $0.20 \pm 0.07$ and $0.56 \pm 0.15$ items/individual in the cockles and green mussels, respectively, during the wet season. The greatest microplastic concentrations were found in April for both species (Table 2). The lowest microplastic concentrations were found in July for cockles $(0.28 \pm 0.05$ items/individual $)$ and August for green mussels ( $0.65 \pm 0.13$ items/individual).

The lower hydrodynamic forces (waves, tides, and current) in estuaries may be contributing to the higher abundances of microplastics in bivalve observed in April (dry season) than in the wet season. 
During the dry season, this results in a higher number of microplastics being deposited on the sediment and floating in the water column, which possibly transferred to bivalve because it is an important food sources for them. Even high runoff flux during the wet season might transport more microplastics from the land into estuaries [30] and the increased hydrodynamic force during the wet season may make microplastic deposition into sediments more difficult [31-33] which may caused a lower amount of microplastics in the aquatic environment in the wet season. In addition, cockles and mussels with the smallest tissue weights received more microplastics than those with bigger tissue weights. This pattern also reported in green mussels and clams in Bandon Bay, Thailand [34] and blue mussels (Mytilus edulis) on the UK's south-west coast [35]. This might be attributed to the decrease in filtration rate of bivalves. The filtration rate of larger bivalves is lower [36], which prevents them from ingesting more microplastics per weight than their smaller counterparts [34]. Besides, some bivalves have the ability to reject some of the ingested particles, including microplastics.

Overall, green mussels sampled were more contaminated by microplastics when compared with cockles. The greater microplastics concentrations found in mussels compared to cockles $(\mathrm{P}<0.05)$ may be attributed to differences in habitat types; the green mussels were farmed on plastic ropes, while cockles were grown in sediment. Moreover, the greater concentration of microplastics in mussels can be attributed to fishery activities [24] and plastic materials widely used in mussel farms [37]. In comparison, there was no significant difference in the abundance of microplastics in samples taken from cockles and mussels between the two seasons $(\mathrm{P}>0.05)$. This result is unexpected because the higher precipitation during the wet season caused an increase of surface runoff that transported plastic litter from land to streams and rivers and eventually into Kadae estuary. However, a low variation of precipitation between the two seasons were observed, which may affected to a minor different of microplastics abundance in the two bivalves species in this study area. In addition, due to the sample collections have been done from April to August which also included the transitional period between dry and wet season. Whereas, the environmental conditions may are less different in the study area. The other studies reported the contamination of microplastics pollution in the mid-dry and mid-wet season [34,38] in the South of Thailand. While, this present study will provided some missing information for performing an environmental risk assessment of microplastics pollution during the transitional period between the two seasons in the study area. The mean microplastics concentrations in the present study were lower than concentrations recorded in samples along the coasts of China [15,39], France [25], and the United Kingdom [40], as well as the Ionian Sea in Greece [41]. Moreover, the study conducted in Bandon Bay [34] reported higher concentrations than in our study area. The high abundance of microplastics reported by Chinfak et al. [34] may correspond to an area of shellfish habitat that tends to receive more land-based sources from river runoff than our study site. Additionally, this present study sampled green mussels of a larger size than those recorded in the Chinfak et al. [34] study. This might contribute to a lower concentration of microplastics, because the infiltration rate is less in larger bivalves, preventing them from ingesting more microplastics per unit of weight than their smaller counterparts [42]. Furthermore, differences in microplastic concentrations in organisms are related to the level of microplastic pollution in the environment, a given species' preference for synthetic material intake, and feeding strategy [43].

Table 2 Average concentration of microplastics in green mussels and cockles sampled during April August 2019.

\begin{tabular}{cccc}
\hline \multirow{2}{*}{ Seasons } & Month & \multicolumn{2}{c}{$\begin{array}{c}\text { Average concentration of microplastic } \\
\text { (items/individual) }\end{array}$} \\
\cline { 2 - 4 } & & \multicolumn{1}{c}{ Cockle } & $3.43 \pm 0.21$ \\
Dry season & April & $2.14 \pm 0.36$ & $0.75 \pm 0.09$ \\
\hline \multirow{2}{*}{ Wet season } & May & $0.29 \pm 0.06$ & $1.26 \pm 0.10$ \\
& Average & $0.30 \pm 0.07$ & $0.92 \pm 0.23$ \\
& June & $0.33 \pm 0.04$ & $0.75 \pm 0.12$ \\
& July & $0.28 \pm 0.05$ & $0.65 \pm 0.13$ \\
\cline { 2 - 4 } Average two seasons & August & $0.36 \pm 0.06$ & $0.56 \pm 0.15$ \\
\cline { 2 - 4 } & Average & $0.20 \pm 0.07$ & $0.81 \pm 0.16$ \\
\hline
\end{tabular}


Pearson correlation analysis was employed to investigate the relationship between microplastic concentrations with shell size (length, height, and weight) of the bivalves. The results showed that microplastic abundance was positively correlated to increasing shell heights of bivalves $(\mathrm{r}=0.841, \mathrm{P}>$ $0.01)$ and negatively correlated with weight $(\mathrm{r}=-0.644, \mathrm{P}<0.01)$ (Table 3). Similar positive correlations between microplastic abundance and size of crustaceans were reported by Akhbarizadeh et al. [44], Hara et al. [45] and Hossain et al. [46].

Table 3 The correlation between height, length, and weight with microplastic abundance in the bivalves.

\begin{tabular}{ccccc}
\hline & $\begin{array}{c}\text { Microplastic } \\
\text { concentration }\end{array}$ & $\begin{array}{c}\text { Height } \\
(\mathbf{m m})\end{array}$ & $\begin{array}{c}\text { Length } \\
(\mathbf{m m})\end{array}$ & Weight (g) \\
\hline Microplastic concentration & 1 & 1 & & \\
Height $(\mathrm{mm})$ & $0.841^{* *}$ & -0.103 & & 1 \\
Length $(\mathrm{mm})$ & -0.028 & $-0.548^{* *}$ & 0.058 & 1 \\
Weight $(\mathrm{g})$ & $-0.644^{* *}$ & & \\
\hline
\end{tabular}

** Correlation is significant at the 0.01 level

Microplastic contaminants of different shapes, such as fiber, film, fragment, and pellet were observed in the soft tissues of bivalves (Figure 2). The images in Figure 2 were taken through a microscope. The diversity of microplastic shapes and surfaces indicates the diversity of their sources and a variety of environmental media during the transmission $[39,47]$. Figure 3a shows that fiber particles, in the dry season, are the most commonly identified shape for mussels $(62 \%)$, followed by pellet $(16 \%)$, film (14\%), and fragment ( $8 \%$ ) being the least abundant. Similarly, in the wet season, fiber was also the most abundant shape (69 \%) with the least being fragment (5\%) (Figure 3b). However, with cockles, the dominant shapes were pellets during the dry season (49\%) and fiber during the wet season (59\%), with no film reported in the latter (Figures 3c and 3d). Accordingly, fiber and pellet were documented as the dominant microplastics in this study, which might be related to the high abundance and wide distribution of these types of microplastics in the estuarine environment sampled. Fibers are reported as the most common type of microplastics in rivers, lakes, estuaries, ocean, and effluent from wastewater treatment plants [48]. Fibers are derived from a wide range of sources, including the washing of clothes, the use and wear of plastic products, and the plastic waste generated in industrial production [49-50]. In addition, fiber was previously widely found in several animals, including oysters, brown shrimp, fish, and terrestrial birds [17,51]. The size of microplastic particles ranged from 0.10 to $5 \mathrm{~mm}$, with $4-4.2 \mathrm{~mm}$ and 1 - $2 \mathrm{~mm}$ being the least and most common size classes, respectively (Figure 2). All items found in our study were smaller than $5 \mathrm{~mm}$, fitting the definition of microplastics [5]. 
(a)

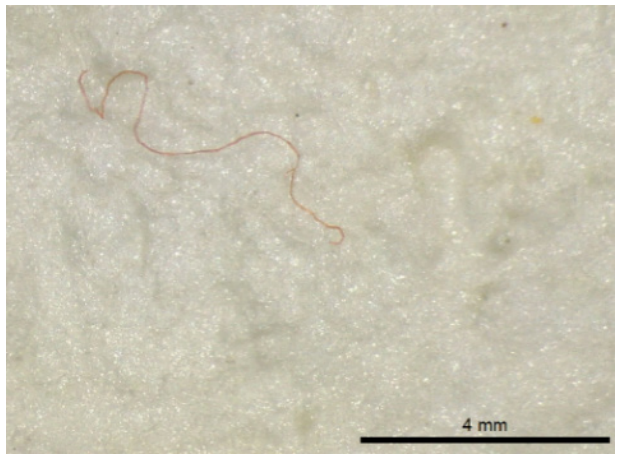

(b)

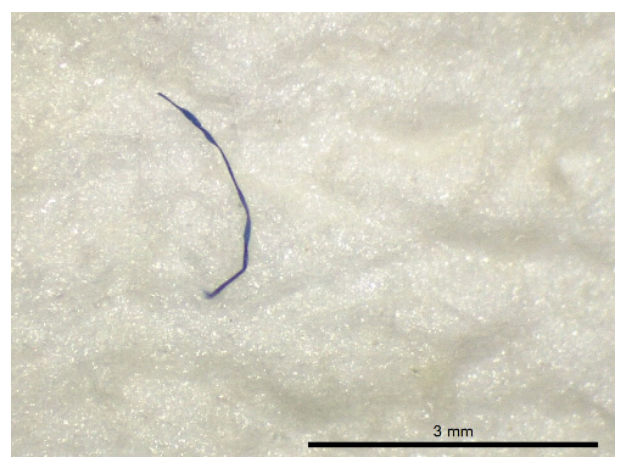

(c)

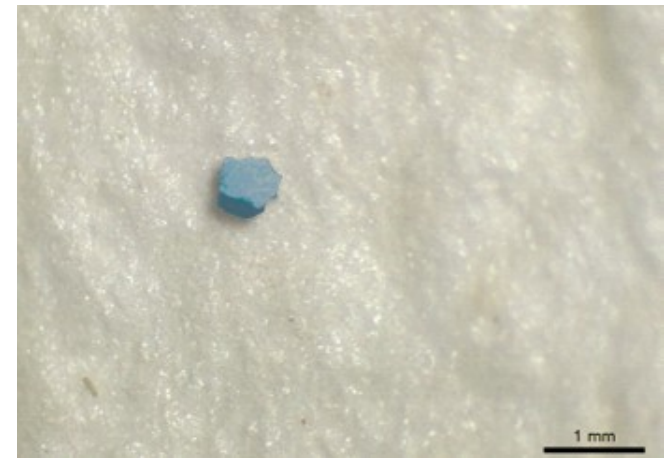

(d)

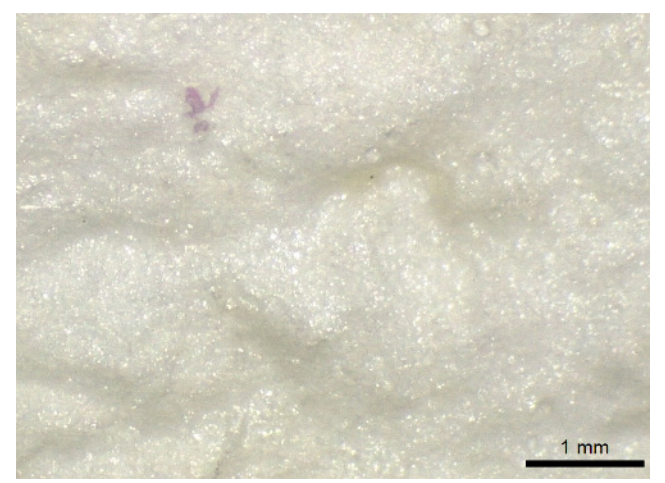

Figure 2 Photographs of different types of microplastics under microscope in bivalves. (a) - (b) Fiber, (c) Pellet, (d) Fragments.

The high abundance of fiber types originated from community anthropogenic activities in urban areas, sea-based activities (fisheries, aquaculture, and tourism), and household activities. Fiber type comes from monofilament fragmentation (single fiber) from fishing nets, ropes, synthesis clothes or clothing fibers. Pellet type of microplastics are primary produced by factories as raw materials for making plastic products. Microplastic with film type is resulted from fragmentation of plastic bags, plastic packaging and low density plastic. Fragment microplastics are sourced from the degradation of large plastic debris [52-53], packaging material, littering, runoff, or wind deposition [54].
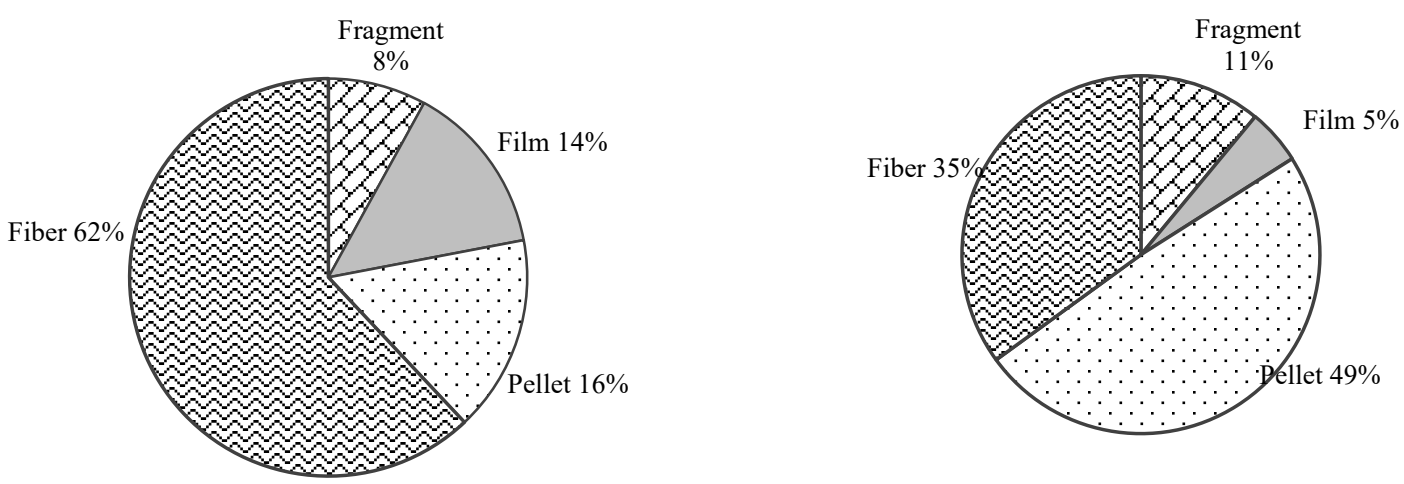
(a) Mussels (dry season)

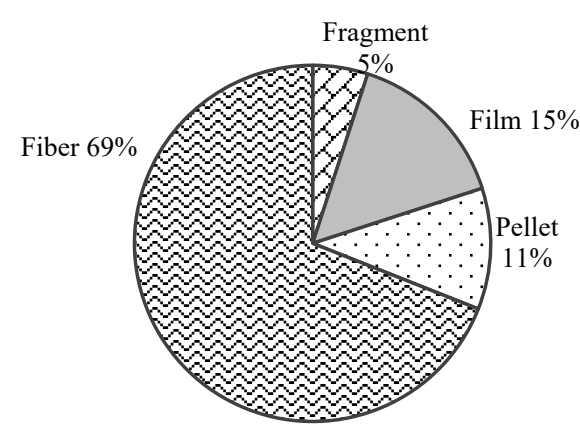

(b) Mussels (wet season) (c) Cockles (dry season)

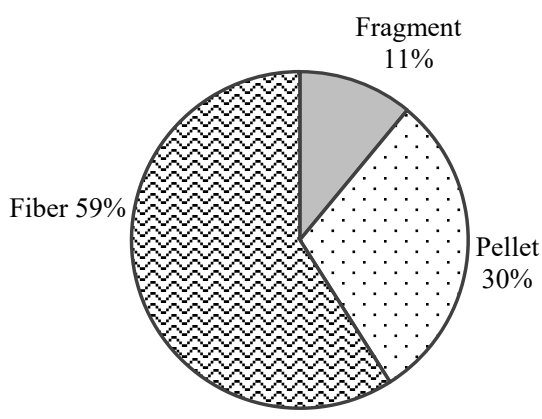

(d) Cockles (wet season)

Figure 3 Percentages of types of microplastics found in two bivalve species: (a) Mussels (dry season); (b) Mussels (wet season); (c) Cockles (dry season); (d) Cockles (wet season).

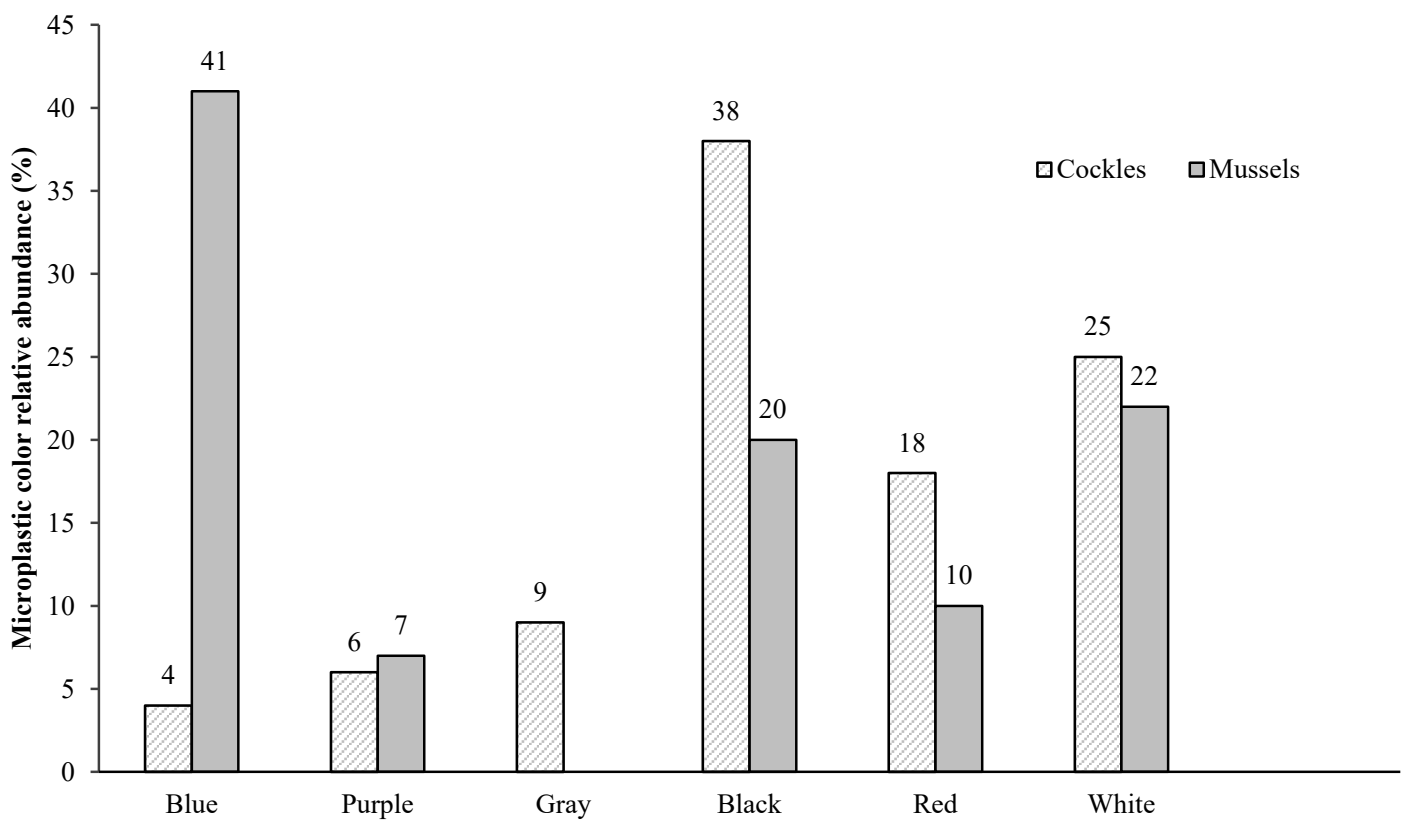

Figure 4 Percentages (\%) of colors of microplastics found in bivalves.

The microplastics sampled in this study were identified as having various colors including black, blue, purple, red, white, and gray (Figure 4), which is consistent with other studies on microplastics $[25,34,38]$. The particles found in cockles were predominantly black $(38 \%)$, whereas the majority of particles found in mussels were blue (41\%) (Figure 4). In our study, the blue particles were the most frequently found in green mussels tissues; this is consistent with the Chinfak et al. [34] findings, with mussels from a different part of Bandon Bay. The majority of black in cockles are possibly caused by either the original color of particles or the color of degradation due to the removal of the original color by photochemical processes or other processes in the environment. Blue particles were also common in mussels from the Ionian Sea in Greece [40] and the Cantabrian Sea, north coast of Spain [55]. It has been suggested that blue, black, white, and red plastic materials are extensively used in mussel farming and 
aquatic cultured in Bandon bay [40]. Therefore, the dominance of blue colors confirmed a high proportion of blue-colored plastic gear. Additionally, the variety of color of microplastics could be related to a wide range of sources [56] and faced by environmental factors during the transmission process, turning the corresponding polymer itself a color [57]. The color diversity to some extent of paticles are likely to be influenced by shape of microplastics. For instance, the color of the film was mainly transparent. The findings of this investigation confirms the prevalence of microplastics in bivalves from Bandon Bay, Gulf of Thailand and signifies a further cautionary sign for marine conservation and the consciousness of human well-being. It is recommended that microplastics pollution in marine organisms and their food must be documented to ensure the safety of both environmental and human health.

\section{Conclusions}

The ingestion of bivalves is of concern as a route of human exposure to microplastics. This study presents the investigation of microplastics contamination in two commercial bivalve, green mussel Perna viridis and cockles Tegillarca granosa (L.) from Bandon bay, Surat Thani Province of Thailand. Our results indicate that microplastic pollution is widespread in bivalves sold in markets, suggesting their potential as a route of microplastic exposure for humans. The green mussels contained more microplastics than cockles, and smaller tissue of bivalve contained relatively more microplastics than larger ones. The greatest abundance of microplastics was recorded in April (the dry season) for both bivalves. Fibers and colored particles were dominant in both seasons, suggested that the microplastics mainly originated from anthropogenic sources. The microplastics collected in this study were mainly small-sized particles, with a large proportion of them in the $1-2 \mathrm{~mm}$ size range. Bivalve may serve as the sink for microplastics in Bandon Bay. However, seasonal variations of microplastic contaminations were not established in the present study. We recommend continuing the study by analyzing samples collected from November to March for the completion of data. Therefore, this study provided some information that can be used for a risk assessment, to identify the pollution status of the research area, and aid in controlling and remediating microplastic pollution at specific points and by region.

\section{Acknowledgements}

The author would like to express sincere thanks to the Faculty of Science and Technology, Suratthani Rajabhat University, in terms of facilities and scientific equipment. The authors are also thankful to the local fisherman from Pak Kadae community for their help in collecting bivalve samples.

\section{References}

[1] RC Thomspson, SH Swan, CJ Moore and FSV Saal. Our plastics age. Philos. Trans. R. Soc. Lond. B Biol. Sci. 2009; 364, 1973-6.

[2] M Eriksen, LCM Lebreton, HS Carson, M Thiel, CJ Moore, JC BBorerro, F Galgani, PG Ryan and J Reisser. Plastic pollution in the world's oceans: More than 5 trillion plastic pieces weighing over 250,000 tons a float at sea. PloS One 2014; 9, e111913.

[3] J Li, AL Lusher, JM Rotchell, S Deudero, A Turra, ILN Brate, C Sun, MS Hosssain, Q Li, P Kolandhasamy and $\mathrm{H}$ Shi. Using mussel as a global bioindicator of coastal microplastic pollution. Environ. Pollut. 2019; 244, 522-33.

[4] MA Browne, T Galloway and R Thompson. Microplastic-an emerging contaminant of potential concern? Integrated. Environ. Assess. Manag. 2007; 3, 559-61.

[5] C Arthur, J Baker and H Bamford. In: Proceedings of the International Research Workshop on the Occurrence, Effects and Fate of Microplastic Marine Debris. NOAA Technical Memorandum NOSOR\&R30, 2009.

[6] DKA Barnes, F Galgani, RC Thompson and M Barlaz. Accumulation and fragmentation of plastic debris in global environments. Philos. Trans. R. Soc. Lond. B Biol. Sci. 2009; 364, 1985-98.

[7] LS Fendall and MA Sewell. Contributing to marine pollution by washing your face. Microplastics in facial cleansers. Mar. Pollut. Bull. 2009; 58, 1225-8.

[8] AL Andrady. Microplastics in the marine environment. Mar. Pollut. Bull. 2011; 62, 1596-605.

[9] J Teng, Q Wang, W Ran, D Wu, Y Liu, S Sun, H Liu, R Cao and J Zhao. Microplastic in cultured oysters from different coastal areas of China. Sci. Total Environ. 2019; 653, 1282-92.

[10] RE Engler. The complex interaction between marine debris and toxic chemicals in the ocean. Environ. Sci. Technol. 2012; 46, $12302 \mathrm{e} 12315$. 
[11] MA Browne, SJ Niven, TS Galloway, SJ Rowland and RC Thompson. Microplastic moves pollutants and additives to worms, reducing functions linked to health and biodiversity. Curr. Biol. 2013; 23, 2388e 2392.

[12] PP Gandara E Silva, CR Nobre, P Resaffe, CDS Pereira and F Gusmão. Leachate from microplastics impairs larval development in brown mussels. Water Resour. 2016; 106, 364-70.

[13] L Frère, I Paul-Pont, E Rinnert, S Petton, J Jaffré, I Bihannic, P Soudant, C Lambert and A Huvet. Influence of environmental and anthropogenic factors on the composition, concentration and spatial distribution of microplastics: A case study of the Bay of Brest (Brittany, France). Environ. Pollut. 2017; 225, 211-22.

[14] GA Covernton, CM Pearce, HJ Gurney-Smith, SG Chastain, PS Ross, JF Dower and SE Dudas. Size and shape matter: a preliminary analysis of microplastic sampling technique in seawater studies with implications for ecological risk assessment. Sci. Total Environ. 2019; 667, 124-32.

[15] J Li, D Yang, L Li, K Jabeen and H Shi. Microplastics in commercial bivalves from Chaina. Environ. Pollut. 2015; 207, 190-5.

[16] D Neves, P Sobral, JL Ferreira and T Pereira. Ingestion of microplastics by commercial fish off the Portuguese coast. Mar. Pollut. Bull. 2015; 101, 119-26.

[17] CM Rochman, A Tahir, SL Williams, DV Baxa, R Lam, JT Miller, FC Teh, S Werorilangi and SJ Teh. Anthropogenic debris in seafood: Plastic debris and fibers from textiles in fish and bivalves sold for human consumption. Sci. Rep. 2015; 5, 14340.

[18] A Karami, A Golieskardi, YB Ho, V Larat and B Salamatinia. Microplastics in eviscerated flesh and excised organs of dried fish. Sci. Rep. 2017; 7, 5473.

[19] LGA Barboza, AD Vethaak, BR Lavorante, AK Lundebye and L Guilhermino. Marine microplastic debris: An emerging issue for food security, food safety and human health. Mar. Pollut. Bull. 2018; 133, 336-48.

[20] E Danopoulos, M Twiddy and JM Rotchell. Microplastic contamination of drinking water: A systematic review. PLoS One 2020; 15, e0236838.

[21] JS Kim, HJ Lee, SK Kim and HJ Kim. Global pattern of microplastics (MPs) in commercial foodgrade salts: Sea salt as an indicator of seawater MP pollution. Environ. Sci. Technol. 2108; 52, 12819-28.

[22] H Lee, A Kunz, WJ Shim and BA Walther. Microplastic contamination of table salts from Taiwan, including a global review. Sci. Rep. 2019; 9, 10145.

[23] SL Wright and FJ Kelly. Plastic and human health: A micro issue? Environ. Sci. Technol. 2017; 51, 6634-47.

[24] B De Witte, L Devriese, K Bekaert, S Hoffman, G Vandermeersch, K Cooreman and J Robbens. Quality assessment of the blue mussel (Mytilus edulis): comparison between commercial and wild types. Mar. Pollut. Bull. 2014; 85, 146e155.

[25] L Hermabessiere, I Paul-Pont, A Cassone, C Himber, J Receveur, R Jezequel, RE Rakwe, E Rinnert, E Rivieref, C Lambert, A Huvet, A Dehaut, G Duflos and P Soudant. Microplastic contamination and pollutant levels in mussels and cockles collected along the channel coasts. Environ. Pollut. 2019; 250, 807-19.

[26] SMO Azad, P Towatana, S Pradit, B Particia, HTT Hue and S Jualaong. First evidence of existence of microplastics in stomach of some commercial fishes in the lower Gulf of Thailand. Appl. Ecol. Environ. Res. 2018; 16, 7345-60.

[27] Thai Meteorological Department. The climate of Thailand. Thai Meteorological Department, 2015, p. 7.

[28] K Munno, PA Helm, DA Jackson, C Rochman and A Sims. Impacts of temperature and selected chemical digestion methods on microplastic particles. Environ. Toxicol. 2018; 37, 91-8.

[29] IBM Corp. Released. IBM SPSS Statistics for Windows, Version 20.0. IBM, Armonk, NY, 2011.

[30] JH Kang, OY Kwon and KW Lee. Marine neustonic microplastics around the southeastern coast of Korea. Mar. Pollut. Bull. 2015; 96, 304-12.

[31] P Vermeiren, CC Munoz and K Ikejima. Sources and sinks of plastic debris in estuaries: A conceptual model integrating biological, physical and chemical distribution mechanisms. Mar. Pollut. Bull. 2016; 113, 7-16.

[32] AP Krelling, MM Souza, AT Williams and A Turra. Transboundary movement of marine litter in an estuarine gradient: evaluating sources and sinks using hydrodynamic modelling and ground truthing estimates. Mar. Pollut. Bull. 2017; 119, 48-63. 
[33] T Jiwarungrueangkul, $\mathrm{Z}$ Liu and Y Zhao. Terrigenous sediment input responding to sea level change and East Asian monsoon evolution since the last deglaciation in the southern South China Sea. Glob. Planet. Change 2019; 174, 127-37.

[34] N Chinfak, P Sompongchaiyakul, C Charoenpong, H Shi, T Yeemin and J Zhang. Abundance, composition, and fate of microplastics in water, sediment, and shellfish in the Tapi-Phumduang River system and Bandon Bay, Thailand. Sci. Total Environ. 2021; 781, 146700.

[35] N Scott, A Porter, D Santillo, H Simpson, S Lloyd-Williams and C Lewis. Particle characteristics of microplastics contaminating the mussel Mytilus edulis and their surrounding environments. Mar. Pollut. Bull. 2018; 146, 125-33.

[36] F Sylverter, J Dorado, D Boltovskoy, J Angela and C Daniel. Filtration rates of the invasive pest bivalve Limnoperna fortunei as a function of size and temperature. Hydrobiologia 2005; 534, 71-80.

[37] A Mathalon and P Hill. Microplastic fibers in the intertidal ecosystem surrounding Halifax Harbor, Nova Scotia. Mar. Pollut. Bull. 2014; 81, 69-79.

[38] T Jiwarungrueangkul, J Phaksopa, P Sompongchaiyakul and D Tipmanee. Seasonal microplastic variations in estuarine sediments from urban canal on the west coast of Thailand: A case study in Phuket province. Mar. Poll. Bull. 2021; 168, 112452.

[39] J Li, X Qu, L Su, W Zhang, D Yang, P Kolandhasamy, D Li and H Shi. Microplastics in mussels along the coastal waters of Chaina. Environ. Pollut. 2016; 214, 177-84.

[40] L Li, M Li, H Deng, L Cai, H Cai, B Yan, J Hu and H Shi. A straightforward method for measuring the range of apparent density of microplastics. Sci. Total Environ. 2018; 639, 367-73.

[41] N Digka, C Tsangaris, M Torre, A Anastasopoulou and C Zeri. Microplastics in mussels and fish from the Northern Ionian Sea. Mar. Pollut. Bull. 2018; 135, 30e40.

[42] C Walkinshaw, PK Lindeque, R Thompson, T Tolhurst and M Cole. Microplastics and seafood: Lower trophic organisms at highest risk of contamination. Ecotoxicol. Environ. Saf. 2020; 190, 110066.

[43] C Walkinshaw, PK Lindeque, R Thompson, T Tolhurst, and M Cole. Microplastics and seafood: Lower trophic organisms at highest risk of contamination. Ecotoxicol. Environ. Saf. 2020; 190, 110066.

[44] R Akhbarizadeh, F Moore and B Keshavarzi. Investigating microplastics bioaccumulation and biomagnification in seafood from the Persian Gulf: A threat to human health? Food Addit Contam. 2019; 36, 1696-708.

[45] J Hara, J Frias and R Nash. Quantification of microplastic ingestion by the decapod crustacean Nephrops norvegicus from Irish waters. Mar. Pollut. Bull. 2020; 152, 110905.

[46] MS Hossain, MS Rahman, MN Uddin, SM Sharifuzzaman, SR Chowdhury, S Sarker and MSN Chowdhury. Microplastic contamination in Penaeid shrimp from the Northern Bay of Bengal. Chemosphere 2020; 238, 124688.

[47] X Guo, Y Yin, C Yang and Z Dang. Maize straw decorated with sulfide for tylosin removal from the water. Ecotoxicol. Environ. Saf. 2018; 152, 16-23.

[48] FS Cesa, A Turra and J Baruque-ramos. Synthetic fibers as microplastics in the marine environment: A review from textile perspective with a focus on domestic washings. Sci. Total Environ. 2017; 598, 1116e1129.

[49] MA Browne, P Crump, SJ Niven, E Teuten, A Tonkin, T Galloway and R Thompson. Accumulation of microplastic on shorelines woldwide: Sources and sinks. Environ. Sci. Technol. $2011 ; \mathbf{4 5}, 9175-9$.

[50] M Claessens, SD Meester, LV Landuyt, KD Clerck and CR Janssen. Occurrence and distribution of microplastics in marine sediments along the Belgian coast. Mar. Pollut. Bull. 2011; 62, 2199-204.

[51] AJR Watts, MA Urbina, S Corr, C Lewis and TS Galloway. Ingestion of plastic microfibers by the crab Carcinus maenas and its effect on food consumption and energy balance. Environ. Sci. Technol. 2015; 49, 14597-604.

[52] MA Browne, P Crump, SJ Niven, E Teuten, A Tonkin, T Galloway and R Thompson. Accumulation of Microplastic on shorelines worldwide: Sources and sinks. Environ. Sci. Technol. 2011, 45, 9175-9.

[53] M Cole, P Lindeque, C Halsband and TS Galloway. Microplastics as contaminants in the marine environment: A review. Mar. Pollut. Bull. 2011; 62, 2588-97.

[54] J Brahney, M Hallerud, E Heim, M Hahnenberger and S Sukumaran. Plastic rain in protected areas of the United States. Science 2020; 368, 1257-60.

[55] P Reguera, L Viñas and J Gago. Microplastics in wild mussels (Mytilus spp.) from the north coast of Spain. Sci. Mar. 2019; 83, 337-47. 
[56] A Gallagher, A Rees, R Rowe, J Stevens and P Wright. Microplastics in the Solent estuarine complex, UK: An initial assessment. Mar. Pollut. Bull. 2016; 102, 243-9.

[57] G Wang, J Lu, W Li, J Ning, L Zhou, Y Tong, Z Liu, H Zhou and Ni Xiayihazi. Seasonal variation and risk assessment of microplastics in surface water of the Manas River Basin, China. Ecotoxicol. Environ. Saf. 2021; 208, 111477. 